Volume 7, Issue 2 (Summer 2015)

\title{
The Amsterdam Civic Guard Pieces within and outside the New Rijksmuseum Pt. V: Govert Flinck
}

D. C. Meijer Jr. (Tom van der Molen, translator)

t.vandermolen@amsterdammuseum.nl

Recommended Citation:

D.C. Meijer Jr. (Tom van der Molen, translator), "The Amsterdam Civic Guard Pieces within and outside the New Rijksmuseum Pt. 5: Govert Flinck," JHNA 7:2 (Summer 2015) DOI: 10.5092/ jhna.2015.7.2.5

Available at https://jhna.org/articles/amsterdam-civic-guard-pieces-within-outside-new-rijksmuseum-partt-5-govert-flinck/

Published by Historians of Netherlandish Art: https://hnanews.org/ Republication Guidelines: https://jhna.org/republication-guidelines/

Notes: This PDF provided for reference purposes only and may not contain all the functionality or features of the original, online publication. This PDF provides paragraph numbers as well as page numbers for citation purposes.

ISSN: 1949-9833 


\title{
THE AMSTERDAM CIVIC GUARD PIECES WITHIN AND OUT- SIDE THE NEW RIJKSMUSEUM PART V: GOVERT FLINCK
}

\author{
D. C. Meijer Jr. (Tom van der Molen, translator)
}

This fifth and last installment of D. C. Meijer Jr's article on Amsterdam civic guard portraits focuses on works by Govert Flinck (Oud Holland 7 1889]: 45-60). Meijer's article was originally published in five installments in the first few issues of the journal Oud Holland. For translations (also by Tom van der Molen) of the first two installments on Nicolaes Eliasz. Pickenoy (among others) and Rembrandt's Nightwatch, respectively, see JHNA 5, no. 1 (Winter 2013); for the third, on Bartholomeus van der Helst, see JHNA 6, no. 1 (Winter 2014); and for the fourth, on Thomas de Keyser, see JHNA 6, no. 2 (Summer 2014). D0l: 10.5092/jhna.2015.7.2.5

The founding of the new building of the Arquebusier Civic Guard Hall has proved of such great consequence for Dutch painting, that it would have been truly a pity if we could not know the gentlemen who made possible the building of the hall for which Rembrandt and Van der Helst delivered their most splendid paintings.

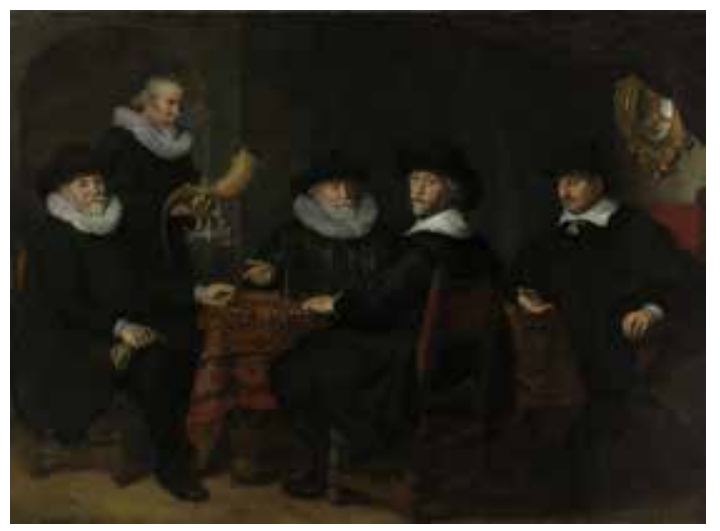

Fig. 1 Govert Flinck, Governors of the Arquebusiers Civic Guard Hall, 1642, Rijksmuseum Amsterdam, inv. no. SK-C-370 (on loan from the city of Amsterdam) (artwork in the public domain)

We are therefore inclined to forgive the vanity of the four governors, who, after the building was finished in 1642, had their portraits painted for placement on the chimney on the west side of the hall [fig. 1]. ${ }^{1}$ Those governors were: Burgomaster Albert Coenraedsz Burgh, Alderman Pieter Reael, and the council members Jan van Vlooswijck and Jacob Willekens. The latter was the commander who, while still retaining his rank in the Amsterdam Civic Guards, had conquered the Allerheiligen-Baai [Baia de Todos Santos, near Salvador] in Brazil for the West India Company. 
The gentlemen did not choose Rembrandt but one of his former pupils who was in the process of emancipating himself from his teacher's influence, being

\section{Govert Flinck}

As a matter of fact, Flinck was [earlier] a pupil of Lambert Jacobsz, the artist and Mennonite teacher. His coreligionist Vondel had bade farewell to him in 1620 in a wedding poem when Jacobsz left for Leeuwarden where he had found his [bride] Aecht. ${ }^{2}$ Ten or twelve years later when he visited the city of Cleves, Jacobsz was addressed there by an honorable citizen who had heard his edifying sermon and had learned so much of his [Jacobsz's] modest way of life that he asked if he could entrust him with his son. The son had an unquenchable inclination for the art of painting. ${ }^{3}$ Lambert Jacobsz took the boy to Leeuwarden and taught him, together with his own son Abraham (later in Leiden called van de Tempel) ${ }^{4}$ and Jacob Backer. A couple of years later he sent Backer and Flinck to Amsterdam ${ }^{5}$ to stay for some time in the workshop of Rembrandt, which was so frequently visited. ${ }^{6}$ Flinck took part there in the exercise Rembrandt set his pupils on the subject of the blessing of Jacob by Isaac [fig. 2], the depiction of which he would repeat a

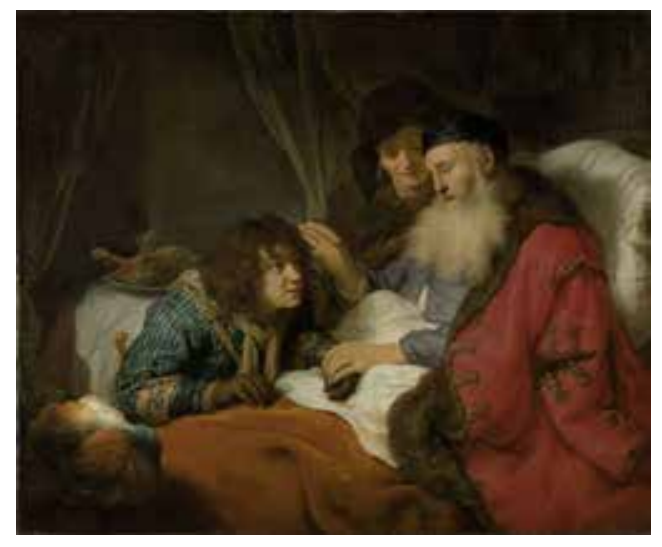

Fig. 2 Govert Flinck, Isaac Blesses Jacob, ca. 1638,

Rijksmuseum Amsterdam, inv. no. SK-A-110

(artwork in the public domain)

number of times later on. ${ }^{7}$ But he soon left that invaluable school and became independent. ${ }^{8}$ Already at the age of twenty-one (he had been born on January 25,1615 ) he painted a shepherdess that is presently in the museum in Braunschweig ${ }^{9}$ and the portrait of Jacob Dircksz Leeuw, which has been discovered in the Rijpenhofje in 1876 by A. D. de Vries. ${ }^{10}$ After that, various distinctive portraits focused attention on his talent -- the young soldier now in the Hermitage, ${ }^{11}$ the gray man now in Dresden (1639), ${ }^{12}$ the shepherdess from the Louvre (1641), ${ }^{13}$ and the portrait of a woman (1641), which has gone into the collections of the Berlin Museum from the Suermondt gallery. ${ }^{14}$ This resulted in the confident commission of the group portrait that shows the governors of the Arquebusiers Civic Guard. He fulfilled the task commendably, as we can still judge nowadays (although it seems to me that the painting has not been spared overpainting) in the third section of the Gallery of Honor to the right [in the Rijksmuseum], where it received a rather high place on the wall. The composition is the usual: four gentlemen in black, wearing hats, seated on chairs with red-leather backs on four sides of a table covered with a Smyrna rug. The man sitting on the side of the table towards the spectator is turning his head. Two others give the impression, from their hand gestures, of being in quite a lively conversation. The stage is enlivened a bit by the figure of an old man (a well-painted head), who -- bareheaded -- arrives to place the guild drinking horn on the table -- the sixteenth-century buffalo horn with a silver foot in the shape of a tree 
trunk flanked by a lion and a dragon [fig. 3]. ${ }^{15}$ In the top right corner, the dark background of the painting is broken by a shield in a heavily ornamented gilt frame. On the shield, a golden bird's claw is visible, the old symbol of the Arquebusiers. ${ }^{16}$

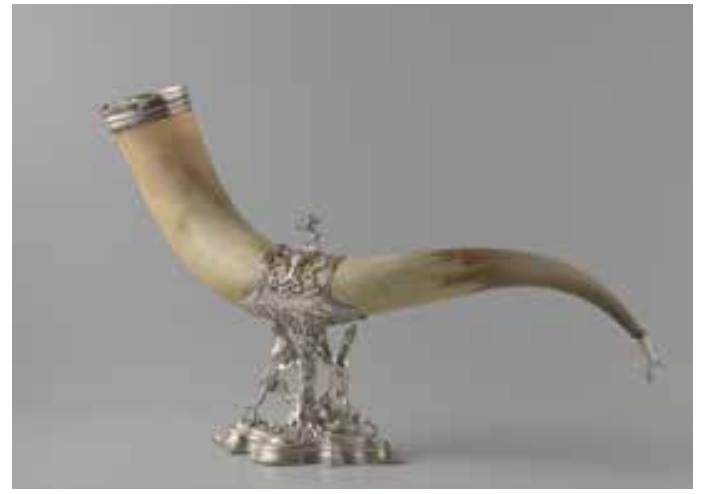

Fig. 3 Attributed to Arent Cornelisz Coster, Drinking Horn of the Arquebusiers Civic Guards, 1547, Rijksmuseum Amsterdam, inv. no. BK-AM-12 (on loan from the city of Amsterdam) (artwork in the public domain)

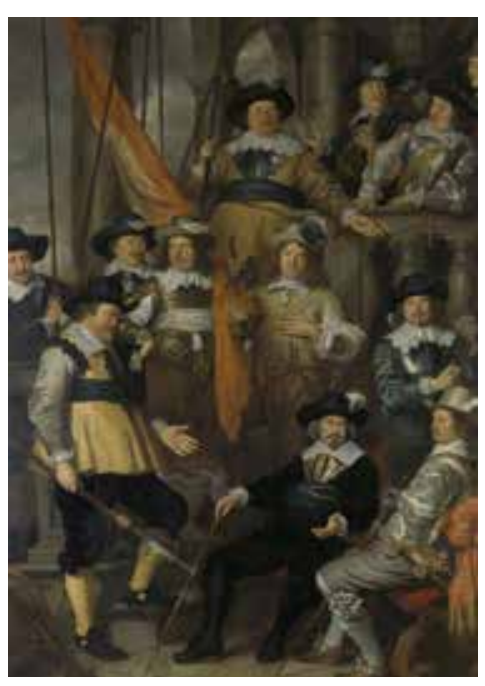

Fig. 4 Govert Flinck, Company of Albert Bas and Lucas Conijn, 1645, Rijksmuseum Amsterdam, inv. no. SK-C-371 (on loan from the city of Amsterdam) (artwork in the public domain)

The work seems to have been executed to the satisfaction of the civic guards; at least, a couple of years later (1645) Flinck was honored with the commission of another civic guard painting [fig. 4] for adorning the same room [in the Arquebusiers Civic Guard Hall], later in the burgomasters room in the town hall on Dam square, from which it was brought to the Rarities, or Weapon, room of the present town hall. ${ }^{17}$ Nowadays it has a deserving place in the Rembrandt Room of the [Rijks]museum, where it acts as a pendant to the Sandrarts ${ }^{18}$ on the other side of the doorway, just as those paintings used to hang, on both sides of the fireplace in the Arquebusiers Civic Guard Hall. It is without a doubt Flinck's masterpiece and one of the finest products of the Dutch school of painting, warm of tone and rich in color, full of beautiful figures, well modeled and ordered with great judgment. Rembrandt's influence is not traceable in the painting. It rather seems that Flinck wanted to surpass that of Van der Helst from 1639, and if his talent needed a greater master to inspire him it was rather Van Dyck than Rembrandt. ${ }^{19}$

6 Because the painter was subject to the measurements of the wall space where the painting was destined to be placed, it is, contrary to most civic guard paintings, higher than it is wide. The attention is drawn first to the powerful features of the lieutenant in a yellow tunic with a blue-green sash, who bending forward with drawn partisan addresses two officers, seated on chairs lined in red and with curled legs, such as we have already encountered on the Four Burgomasters by De Keyser ${ }^{20}$. One of the gentlemen, whose lush, gray strands of hair come from under a black, plumed hat, is dressed stylishly in black velvet. The other one is dressed in a silvery satin, with a heavy orange sash. The latter wears yellow shoes and a white hat. Both gentlemen wear their rapiers on the side and hold canes in their hands, which inclines us to conclude that we see two captains in this painting, although Schaep only names Captain Bas and Lieutenant Conijn. Maybe the work was painted on the occasion of a change of captains. Schaep's notes (probably from the proceedings of the war council) on the changes in the officers of the civic guard ${ }^{21}$ however lack these years. We do know, however, that in 1638 Jacob Simonsz de Vries was still the captain in district eighteen; but we cannot recognize this old man (whom we know from the painting by 
Thomas de Keyser) in one of the captains painted by Flinck. It is likely therefore that another person served as captain in between.

7 Above the officers a large orange flag is visible, decorated with a representation hidden in the folds. The ensign is dressed in gold brocade, with heavily split sleeves, white sash and a white hat. To his left, with his left hand on his chest, is a musketeer in a light yellow-gray tunic, the fork for his gun hangs by an orange rope from his left wrist; on his white hat is a blue plume. Obviously there is no lack of marvelous colors, although both pikemen to the right of the ensign are dressed in black. In the background, four more persons are descending a staircase with a richly decorated balustrade under an arcade of gray stone.

8 These are the civic guardsmen of district eighteen (the same company that De Keyser painted when De Vries was captain and Dirck de Graeff lieutenant). They lived on the Pijpenmarkt [pipe market], for example, Lieutenant Conijn, or opposite on the Deventer Houtmarkt [wood market], later the Bloemmarkt [flower market, both markets are presently part of the Nieuwezijds Voorburgwal], or on the first part of Kalverstraat or Rokin, such as Captain Bas, who in fact lived just outside the district on the southern corner of the Duifjessteeg. In the district itself there certainly was no better person then this patrician, who, a couple of years after Flinck painted him, became burgomaster and whose father had also held that office a couple of times between 1610 and 1637, the year of his death. That father was Dirck Bas, who was knighted in 1616 by Gustav Adolf as a reward for his mediation in the peace between Russia and Sweden, allowing him to move the white lapwing in his coat of arms to the left and adorn the right half with a white eagle holding a green olive branch in his beak, signifying peace.

9 If the art-loving citizens of district eighteen had given Flinck the occasion to show if he could improve on Thomas de Keyser, some years later his talent was even more tested when he was commissioned to paint the civic guards of the district that had recently been painted by none other than Rembrandt: district one. The men in that district had, however, changed completely in those six years; none of the names of the civic guards painted by Rembrandt appears on the list of names in Flinck's work[fig. 5]. ${ }^{22}$

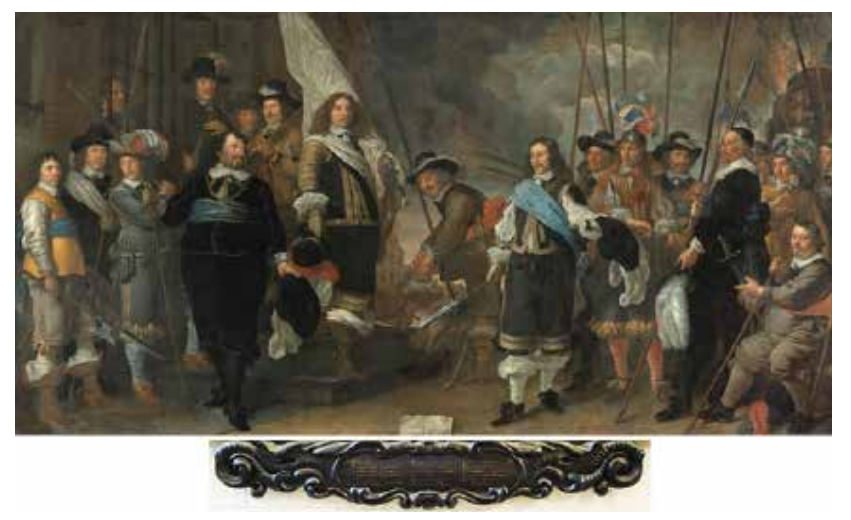

Fig. 5 Govert Flinck, Company of Captain Joan Huydecoper and Lieutenant Frans van Waveren Celebrating the Treaty of Münster, 1650, Amsterdam Museum, inv. no. SA 7318 (artwork in the public domain). Below the painting is the nameplate (Amsterdam Museum, inv. no. KA 28881)

In another way, too, Flinck had a competitor with this painting, someone with whom it was a great honor to be competing. His work that I am now going to describe was destined for the Old Hall of the Crossbow Archers Civic Guard Hall, as a pendant to the Meal of Civic Guards by Van 
der Helst ${ }^{23}$ and, just like this one, it not only had to be a portrait group but also had to have value as a history piece, for it had to express the joy of the Amsterdam citizens over the recent Peace of Munster. It was probably solved by friendly agreement that Van der Helst chose an interior for the depiction of the feast, and Flinck depicted the happy atmosphere in the street.

11 With a lot of tact, Flinck divided his civic guards into two groups. To the left, eight persons descend the low steps of a building which one can consider the civic guard hall itself; the captain is at the front, the ensign, following him, is still on the stairs, other civic guards are behind him in the door, while the sergeant, Appelman, is placed next to the steps with a couple of others, awaiting the captain, who, while facing right, turns his head to the left in greeting. This greeting is meant for the lieutenant, who, at the front of another troop of civic guards walks through the street and, when both have gone a couple of steps more, will join the captain on his left flank and march with him at the head of the troop.

12 The background of the group on the left side is formed by the dark mass of the building from which the civic guards appear. The right group is set off against a cloud of smoke formed by the shots of joy fired by the musketeers accompanying the lieutenant and by the burning tar barrels, which stand in line behind them on the far right of the painting...

13 The connection between both main groups is formed in a fortunate (or unfortunate) way by a civic guard from the group led by the lieutenant. This lieutenant makes use of the moment of standing still to pull up a stocking that had sagged, placing his left foot on one of the steps. I said in a fortunate or unfortunate way because, however fortunate the idea is to obtain an elegant wave in the line of heads by the stooping posture of this person, and however drawn from life this episode might be, this unabashedly prosaic act clashes with the genteel and graceful postures of the other figures. They pose so impeccably that their postures have been denounced as mannered in the past. Some have even asked in joking exaggeration about which professeur de maintien [professor of poise] taught our old Amsterdammers such elegant steps. Do not forget though, before blaming the painter, that in the seventeenth century, a civilized education valued much the effort put into dancing and fencing. Assuming a calculatingly elegant pose cannot have been so unnatural and forced as it seems to us nowadays.

14. Anyway, Flinck has succeeded in really giving space to his figures and breathing air into his painting. And although the tone is less warm then in his painting of 1645, and although his works do not pluck the strings of our hearts as they do when we stand in front of Rembrandt's civic guard painting, nevertheless Flinck's work holds its own well opposite [Van der Helst's] Meal of Civic Guards and every individual portrait is treated outstandingly.

15 We therefore can best look at them one at a time. We do this with all the more attention because this is the only civic guard portrait in Amsterdam that identifies each person with a tiny number on the painting, corresponding to a list of names that has been preserved. ${ }^{24}$

16 This is how we know that the man with the jackboots, pulling up his stocking, is Pieter Meffert, ${ }^{25}$ and that the fat little man who has taken a seat and removed his hat -- warm and tired as he already is from the march -- is the portrait of Mr. Albert ten Brink (the innkeeper of the Oudezi- 
jds Heerenlogement). It [the list] also identifies the musketeer with the plumed helmet, who loads his gun behind the lieutenant and whose figure seems a bit badly drawn (rare with Flinck!), as Johan van der Hoog, or Van der Haag.

17 It is more important that the painter himself also appears in the painting, among the men coming through the door. Not as a civic guardsman, though, because Flinck not only lived in another city district (on the Lauriergracht) but he was not yet a citizen of Amsterdam (he registered as such only in 1652). His weak and pale appearance betrays the constitution that only affords health on the condition of "taking care of oneself." The features correspond with the portrait painted by Gerard van Zijll, whom Blooteling and Vaillant brought into print [fig. 6].

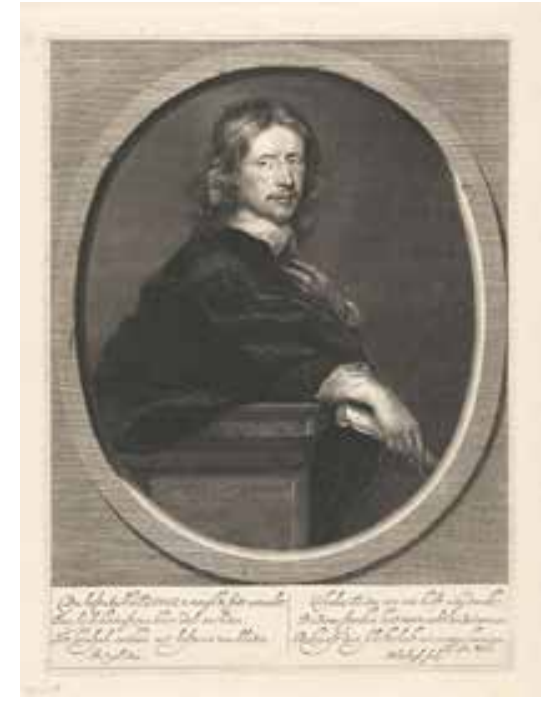

Fig. 6 Abraham Bloteling after Gerard Pietersz van Zijl, Portrait of Govert Flinck, ca. 1660-90, Rijksmuseum Amsterdam, inv. no. RP-P-BI-1819 (artwork in the public domain)

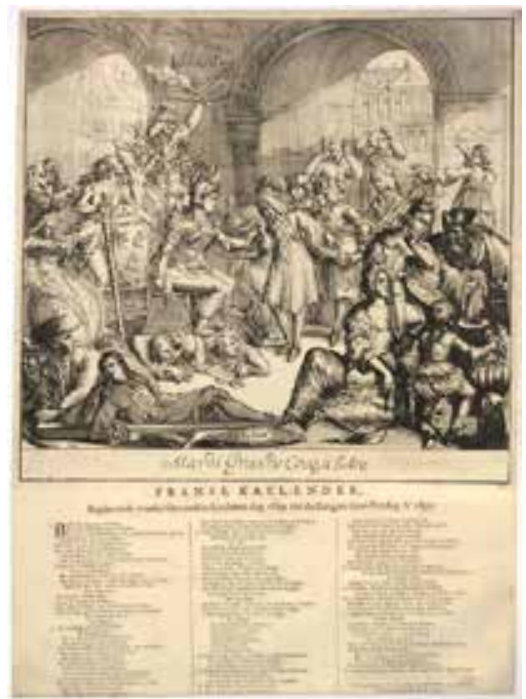

Fig. 7 Romeyn de Hooghe, Mardi Gras de Cocq a l'Ane (A Cock-and-Bull Carnival), 1690, British Museum, London, reg. no. 1868,0808.3396 (artwork in the public domain)

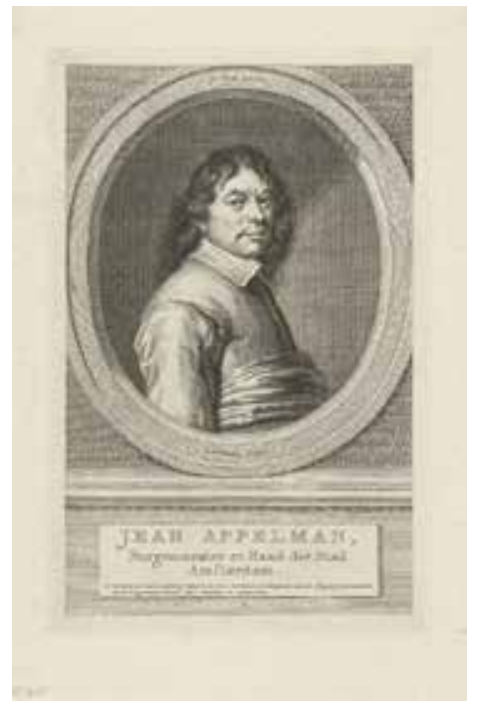

Fig. 8 Jacob Houbraken after Hendrik Pothoven after Govert Flinck, Portrait of Jean Appelman, ca. 1749-59, Rijksmuseum Amsterdam, inv. no. RP-P-0B-48.814 (artwork in the public domain)

18 The sergeant in the group on this side, on the far left of the painting, is Jan Appelman. ${ }^{26}$ This plain name would not suggest that he is the head of one of Amsterdam's oldest families, whose forefathers already occupied city offices before the Reformation, when they lived at the entrance of Nieuwendijk, next to the old town hall. Nor does the portrait that we see before us here -- of the relatively soberly dressed young sergeant with his long hair and cheerful features -- answer in our imagination to the fearsome Amsterdam burgomaster, who, although brought into the council in 1672 by Prince William III himself, later became one of the staunchest adversaries of that prince and his servants. Even the preparations of the assault on England in 1688 had to be kept a secret from him, at the time when they were being drawn up by his fellow burgomasters. Later he became the "black sheep" of the Orange party, to such an extent that he was depicted in cartoons as "barsse Jan" [Surly Jan] who "started to stir in the drunk company at the Arquebusier civic guard hall" courting and being bribed by the French king [fig. 7] ${ }^{27}$ It is a shame that [Jacob] Houbraken, instead of Flinck's civic guard sergeant ${ }^{28}$ did not know or choose the portrait presently adorning the museum in Haarlem, when he engraved the portrait of Burgomaster Appelman, for the illustration of Wagenaars Vaderlandsche Historie [fig. 8]. The latter painting gives such a 
favorable testimony of the abilities of our Amsterdammer Jan Victors as a portrait painter. ${ }^{29}$

19 The other sergeant, in the opposite corner of the painting, is Jacob van Campen, ${ }^{30}$ not the architect of the Amsterdam town hall as was believed in the previous century, to the dismay of Van Dijk, ${ }^{31}$ but his cousin, the brother of the graceful Machteld van Campen who enchanted Huygens on Tesselschade's wedding, but who in May 1626 was plucked from the stem like a flower withering too early. ${ }^{32}$

20 Van Campen has taken his plumed hat off, like the other officers who salute each other courteously, while the other civic guards keep their hats on. His dark attire accentuates the dashing robes adorning Lieutenant Frans van Waveren standing in front of him, whose clothing competes with that worn by his brother, the ensign Nicolaas, who descends the steps with the white standard. Both brothers are sons of the dignified burgomaster Anthony Oetgens van Waveren. Claes later married Burgomaster Willem Backer's daughter and became an alderman in $1665^{33}$; the lieutenant [Frans van Waveren] died unmarried and without occupying an office. Their older brother Johan (the later burgomaster) is the lieutenant in the Meal of Civic Guards by Van der Helst. ${ }^{34}$

21 Let us finally focus our attention on the main character: the captain. Flinck paid much attention to his beautiful head. His heavy-set stature gives the impression that he is acting like one of those self-conscious, energetic burghers, never daunted by even the heaviest burdens of government worries, someone whose determination did not bend even under the most overwhelming torrents of problems. He appears to have been one of those burgomasters who did not work hard to enrich themselves but did it for their citizens, and on whose watch one could safely sleep at night. That sort of personage raised Amsterdam to a city admired by the whole world. Those regents, while disdaining comfort and splendor for themselves, belittling their own pleasures, were not indifferent to literature and art. They were plain and frugal by nature, but loved grandeur, aware of what their rank asked of them. Thus appears before us, both in history and in Flinck's painting, the image of Johan Huydecoper van Maarseveen, the main character and the principal protagonist in the depiction. He is identified as such by the lines of Jan Vos's poem, which were originally legible on a painted piece of paper that seemed to have been inserted between the frame and the painting (they have now been mostly erased by time):

Hier trekt VAN MAARSSEVEEN de eerst' in d'eeuwige vreede.

Zoo trok zyn vaader d'eerst' in t'oorlog voor de Staat.

Vernuft en Dapperheidt, de kracht der vrye steede',

Verwerpen d'oude wrok, in plaats van 't krijgsgewaadt.

Zoo waakt men aan het Y na moorden en verwoesten.

De wyzen laaten 't zwaard wel rusten, maar niet roesten.

[Here VAN MAARSEVEEN leads in eternal peace. 
As did his father lead in the war for the sake of the State.

Wit and bravery, the strength of free cities,

Reject the old resentment, instead of the armor.

This is how they keep watch at the IJ [river] after murder and ruin.

The wise let the sword rest, but not rust.] ${ }^{35}$

22 That father was Jan Jacobsz Bal van Wieringen ${ }^{36}$ with the nickname Huydecoper (probably deriving from his profession, a reference which appears in the three ox heads on his coat of arms as well).

23 That he was a man in whom one could trust is proved by a particularity noted in the family chronicles of the De Graeff family: Dirck Janszoon de Graeff, when he fled to Emden, sent ahead two iron cases with 60,000 guilders to Jan Jacobsz Huydecoper, who had earlier fled the Spanish violence.

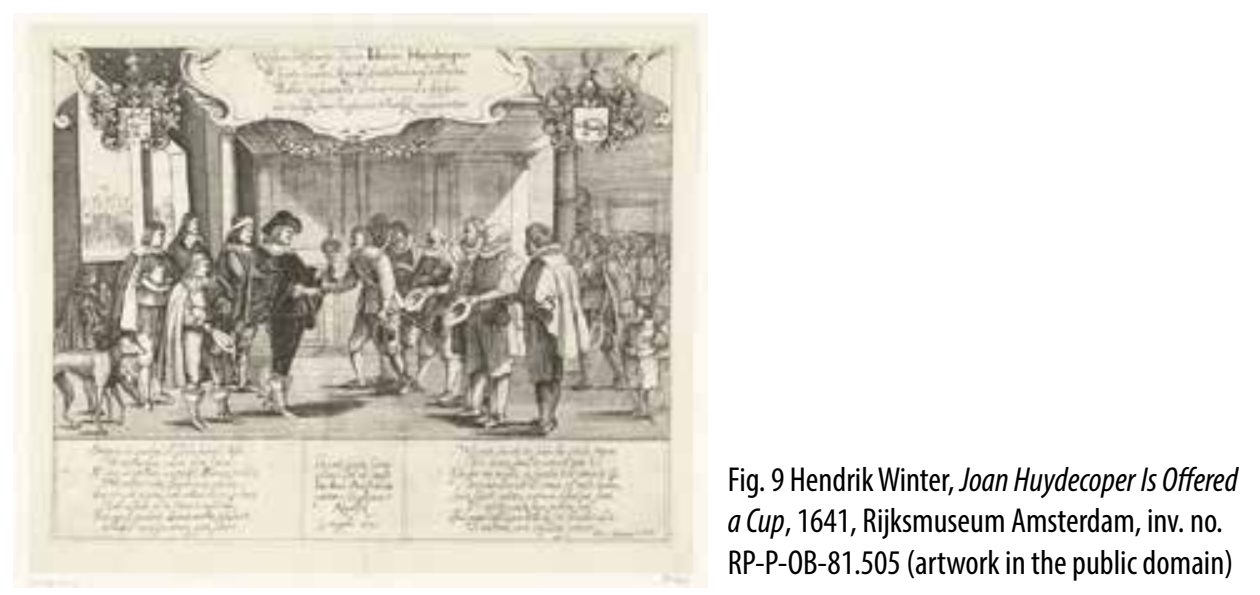

24 That he, too, had fought the Spanish appears from another poem by Vos, ${ }^{37}$ and also from one other fact. During the Alteration of 1578, he headed the company that was the first to keep watch under the slogan "Oranje" -- he was soon promoted to the rank of colonel of the civic guards. He also helped to govern the city as councilor, alderman, and treasurer and died on April 20, 1624. His marriage to Elisabeth van Gemen seems only to have taken place when he had reached an advanced age. As someone who fled the country in 1567, he must have been at least sixty in 1601 when the son was born that we now see before us. ${ }^{38}$ This helps explain the peculiar fact, mentioned by the poet in the verse on the painting that the father helped start the eighty-year war and the son helped end it. In all likelihood, the grandsons of those men of 1567 were now governing the city, while the sons had already passed away. Huydecoper, however, still had a glorious career ahead of him, although in the year in which we meet him, he had already gained multiple honors. After his short-lived first marriage to Elisabeth Pietersdochter Biscchop (1621), in 1624 he married Maria, a daughter from the rich merchants family Coeymans or Coymans. ${ }^{39}$ In 1629 , he was first appointed alderman and in 1630 he joined the council. Around 1638 he was knighted 
by Christina of Sweden and also bought the manors of Blokland and Thamen. He traded that title a couple of years later for that of lord of Maarsseveen and Neerdijk. In 1640, he bought Maarsseveen, opposite the village of Maarsssen [on the river Vecht], a region that had already become charming to rich Amsterdammers, who gladly built their country houses there. After the period when Huydecoper lived there in his country seat Goudesteyn (still existing today), it flourished even more. Therefore, the delighted inhabitants of Maarsseveen festively welcomed their new lord on August 13,1641, and honored him with a beautiful cup. An etching by the little known artist Hendrik Winter recalls that occasion [fig. 9]. From that year onward, Huydecoper proudly adorned the heart of his coat of arms with the black pig of Maarsseveen. But these noble titles did not incline him to neglect trade and shipping, neither in his own business, nor in that of the East India Company, where he served as a governor. Just as energetically, he continued to attend to justice in the college of aldermen. But also the civic guards demanded his service and when Banninck Cocq became colonel, "Amsterdam, full of rivers and gold" seemed "drowned up to the stars in a sea of smoke and fire," from all the shots of joy that were fired when Huydecooper served as the captain in district one. ${ }^{40}$ He lived there, in the house on the Singel near the Vijzelstraat, ${ }^{41}$ one of the more beautiful buildings by Philips Vingboons, which nowadays is still a gem in our town, with its system of pilasters and its neatly cut hardstone gable and which we see depicted in the background of the painting by Flinck [figs. 10, 11]. ${ }^{42}$

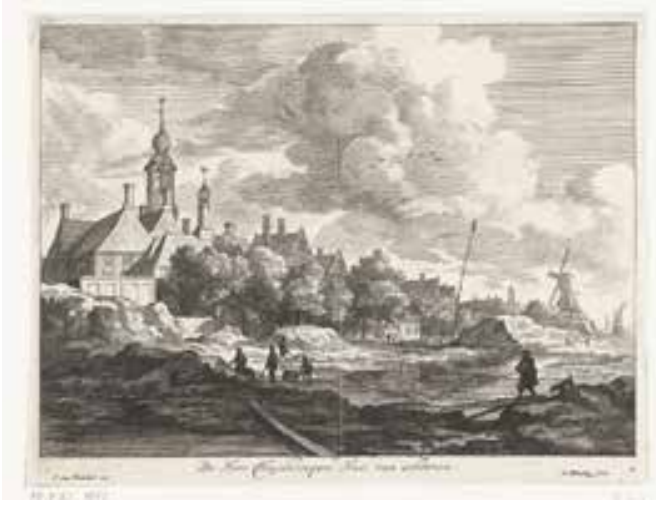

Fig. 10 Abraham Bloteling after Jacob Ruisdael, The House of Joan Huydecoper, Seen from the Rear, with Workers Digging the Herengracht in the Foreground, ca. 1655-90, Rijksmuseum Amsterdam, inv. no. RP-P-BI-1861 (artwork in the public domain)

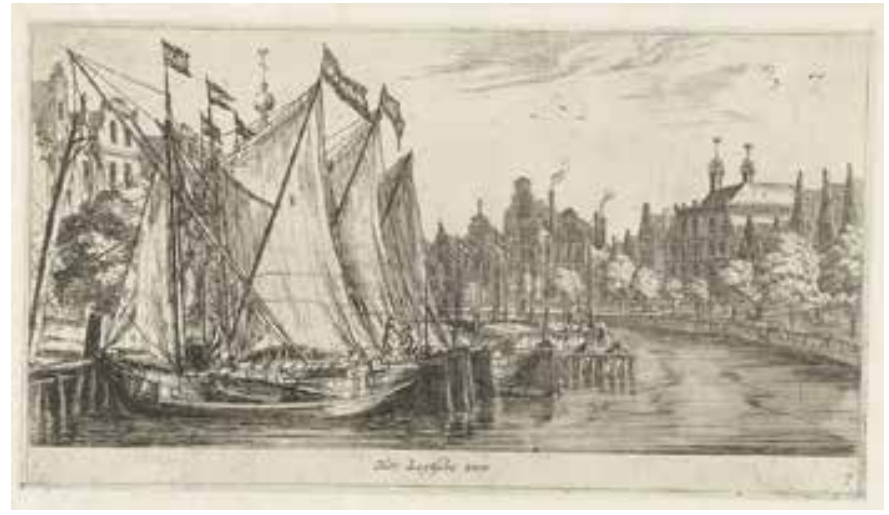

Fig. 11 Reinier Nooms, The Ferry to Leiden, ca. 1657-70, Rijksmuseum Amsterdam, inv. no. RP-P-OB-20.506 (artwork in the public domain)

25 Shortly after the peace celebrations of 1648 the pikes and muskets of the civic guards nearly had to be put to use. The martial qualities would have been tested had the militia sent by Prince Willem II advanced and surprised rebellious Amsterdam. But the diplomatic skills of Huydecoper proved even better than his martial qualities. After having helped Burgomaster Bicker in bringing the city quickly into a state of defense, he participated in negotiations held at the manor Welna, convincing the commander of the stadhouder's troops to refrain from violence. Grateful Amsterdam entrusted Huydecoper with the honor of becoming burgomaster and in 1654 he became a member of the Council of the Admiralty in Amsterdam. The most glorious year in his life was 1655, however, when he was delegated to represent the city in Berlin at a solemn embassy for the baptism of the son of Louise Henriette, Frederik Hendrik's daughter. For political and financial reasons, the city took great interest in its friendship with the Brandenburger and accepted the godfathership over the newborn. Huycedoper brought the christening gift, a letter of interest 
worth 1,000 guilders per year in a gold box. The ivory head, made by the elector himself, that Huydecoper received, served as a proof of the prince's particular satisfaction. Moreover, the prince had an especially friendly relationship with Huydecoper. He had dined at his home and Huydecoper's daughters were honored with gifts by the prince's wife (when she visited Amsterdam officially in 1659). ${ }^{43}$ But the Amsterdam citizenry was also pleased with the embassy. A gold coin, ${ }^{44}$ presently kept in the collection of the Royal Antiquarian Society, was engraved. And one of Huydecoper's former officers in district one led the horse guard of honor when the burgomaster was welcomed upon his return from Berlin with an almost regal triumphal entrance. ${ }^{45}$

26 No less happy a day came for our Huydecoper some months later when, on July 29, he and his fellow burgomaster took their seats in the finished town hall. This was the monument that displayed the glory of Amsterdam to the whole world. He had contributed a great deal himself. As appears at a certain point in Vondel's Inwijding van het Stadhuis he had been a member of a commission, drawn from the council at the time, that prepared the work and chose the best design. ${ }^{46}$

27 In that commission, did Huydecoper choose the design by Vingboons, who built his house on the Singel, the rival design of the one by van Campen? We do not know, but there is no reason to suppose so, because Huydecoper was not a man whose love of the arts was characterized by one-sided preferences. Did he receive Vos's poems in his honor with the same affable smile as those by Vondel? We have seen that he sat for his portrait to Flinck and Van der Helst, yet he also let Jonson van Ceulen portray him. ${ }^{47}$ Jan Lievens portrayed his son. ${ }^{48}$ And many different artists were allowed to decorate the rooms of Goudesteyn and the house on the Singel. The subjects of those paintings, mostly derived from antiquity, are somewhat too academic for our [current] taste. From this [academic taste], it is possible to determine the directions needed to please patrons of that time. Flinck was present in the gallery at Goudesteyn with his representation of Lucretia. Our burgomaster was also interested in sculpture, judging from the fountains and statues that adorned the gardens and vestibules, both in his country house and in his home in Amsterdam. Quellinus also sculpted in marble a life-size bust of the burgomaster in 1654 [fig. 12], for which Vondel wrote muscular verses. Nowadays it can be found with Huydecoper's descendants at Goudesteyn, ${ }^{49}$ where Huygens admired it in 1656:

De lieffelijke locht in allerhande weer

De klaerheit van den stroom en 't blanck hert van den Heer $^{50}$

[The gentle air in weather of all sorts

The clarity of the stream and the fair heart of the Lord]

What deserves special mention is that the lord of Maarsseveen not only showed himself a Maecenas in the sense of buyer and connoisseur of art, but he also demonstrated a humane and friendly way of dealing with artists. We know this from the fact that despite his position as a dignified and powerful burgomaster, he did not deem it below his rank to join the well-known feast of the guild brothers of St. Luke in the Crossbow Civic Guard Hall in 1654. This was where Vondel celebrated the art of painting in his poetry, in thankfulness for the honor bestowed upon him the year before, when he was crowned by Apollo with laurels as the "head of the poets," in the name of the assembled painters. ${ }^{51}$ 


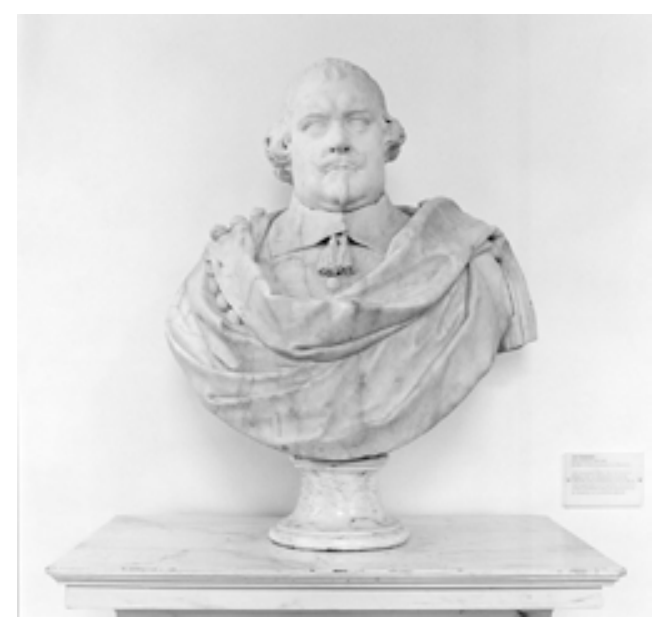

Fig. 12 Artus (I) Quellinus, Portrait Bust of Joan Huydecoper, 1654, Amsterdam Museum, inv. no. BB 208 (on loan from a private collection) (artwork in the public domain)

29 Govert Flinck was probably present at those festivities, though he did not play a big role there. The first, as well as the latter, appears from a rhyme that father Vondel wrote when the noisy artists were making too much of a bustle for his taste and the wine from the cellars of the civic guard hall went to the guests' head all too much. He shoved it over the table to a certain Govert, without doubt our painter, who produced more than one portrait of the poet in these years. ${ }^{52}$ They probably left together, because Flinck seems to have been a quiet and homely man, even if he did not, as is usually supposed, belonged to the reserved Mennonites. ${ }^{53}$ All that we know of him shows that he was committed to a quiet and comfortable domestic life. He was not a man to spoil the esteem that high-ranking persons had of him by an irregular lifestyle, ${ }^{54}$ not only with the regents in the city he lived in but also the sovereigns that ruled his native city in succession: first the elector of Brandenburg, later Prince Johan Maurits of Nassau. His visits to Cleves and the circumstance that he left behind there after his death strengthen the argument of his attachment to the place where he spent his childhood and to his family remaining in that region. ${ }^{55}$ In Amsterdam, however, he made his money; he was well paid and used his fortune like an honorable citizen but also as a civilized man.

30 He had bought two houses on the Lauriergracht (north side), with a shed and garden, running to the Laurierstraat, and he showed off carpets there that were given to him by the elector of Brandenburg and the sculpture by Quellinus that he had collected. ${ }^{56}$ Twice he led a wife into that house, both times a woman from the south of Holland from a good family.

31 On June 3, 1645, he signed his vows in the presence of his father, Teunis Govertsz Flinck, with the twenty-five-year old Ingitta Thovelingh from Rotterdam. Her mother, Maria Dircksz Bos, acted as a witness to the bride, probably the widow of Claes Martensz Thoveling, who was governor of the East India Company in Rotterdam and whose portrait can be seen in the [Rijks]museum in the courtyard with the maritime collection. The widow lived on the Singel at the time, yet six years later we find her on the Lauriergracht next to the Walenweeshuis so perhaps in the house of her son-in-law. This is not certain because her own son, Marten, was unmarried and could also have lived on the Lauriergracht. ${ }^{57}$

32 Already in the next year Ingetje gave Flinck a son, who received the names Claes Anthony. Flinck's marital happiness soon came to a sad end, however, by a miserable disease that his wife 
had already contracted before they married, although she was not very burdened by it and remained cheerful and strong. In the end it worsened so much that death was the final result. She had a swelling (an ovarian cyst) of such dimensions, that her case has been described in medical science as a curiosity, among others by the famous Tulp in his Medicynsche Aenmerkingen. The city doctor Job van Meekeren described the process of the autopsy ${ }^{58}$ that occurred on January 5, 1651, and for which the patient had given her consent. The water drawn from her monstrously swollen abdomen weighed more than 100 pounds!

33 Havard, who translated Van Meekeren's report, concluded that Ingetje had already suffered from the disease before the marriage. ${ }^{59} \mathrm{He}$ added that she belonged to the upper class and that, since Flinck had mortgages on his houses in 1644, it is doubtful whether Flinck's first marriage was motivated by love. It is a pleasure for me -- as a result of of Mr. Abraham Bredius's kindness -- to offer proof that Flinck did not need to marry a sickly wife for her fortune. This appears from Flinck's testament, made before the Amsterdam notary J. van Loosdrecht, together with the prenuptial agreement, signed June 2, 1645. From this agreement it becomes clear that Govert Flinck brought f16.000 into the marriage, represented by the houses on the Lauriergracht and by paintings, prints, and many other things that belong to the art of painting, while the bride brought in f6.000 guilders in cash and interest letters [documents indicating the right to an annual income of interest from a sum of money]. If the man had died childless, his bride would pay his heirs f10.000; if the opposite, Flinck would be held to pay f4000, to the Thoveling family. It is clear: this is not a case of a poor painter marrying a rich girl after all!

34 On April 19, 1646, the prenuptial agreement was replaced by a testament of the married couple, not because of the sad health conditions of Ingetje after the child's birth, as Havard thought, but because of her pregnancy. In the will, the child or children were proclaimed heirs, excluding usufruct, guaranteed to the surviving parent. In addition, it specified a payment of f5000 to the testate's family, if he [Flinck] died first, and f2000 to be paid by the widower to the family of the wife, if she should die first. ${ }^{60}$ Flinck adhered to this testament when on May 23, 1656, he secured f10.000 for his ten-year-old son (who would be given a stepmother), for his mother's share, as Havard published from the archive of the orphan chamber. ${ }^{61}$

35 Maerten Claesz Thovelingh, the brother of the child's mother, acted as guardian. He himself had declared the child to be his universal heir in 1652, except for a bequest of f1500 to the children of Govert Crabeth in Gouda. ${ }^{62}$ From the latter, it appears that the Thovelingh family also had relations in Gouda and therefore it is not improbable that we may see a relative of Flinck's first wife in the woman from Gouda, Sofia van der Houve, whom Flinck took as his second wife on May 30, $1656 .{ }^{63}$ If we are to believe Vondel, ${ }^{64}$ who recited a poem at the wedding, many a Diana or Magdalen who left Flinck's workshop at that time involuntarily revealed features if his beloved Sofia.

36 How happy must the artist have felt that, precisely in that year, ${ }^{65}$ he could paint the allegorical figure after which his chosen had been named: the heavenly Sophia, divine wisdom. The Amsterdam regents, who were not ashamed to demonstrate that they did not hold human intelligence for the highest in the universe, wished to see painted in the council room in the new town hall, the daily example of Solomon's prayer for wisdom [fig. 13]. Flinck also depicted Wisdom descending from higher spheres because of Solomon's prayers. But his work was not happily inspired. His Wisdom 
is anything but an ethereal figure: nothing more than a woman seated on clouds, illuminated by a cold and soulless light. The kneeling Solomon is more successful, and the groups of surprised priests and Levites are brought into the painting expeditiously as filler, without distracting too much. But regardless, the painting leaves us indifferent; it is languid and without exaltation. No trace left of the deep feelings, nor the ingenious originality of the artist who had once been Flinck's teacher -- no trace of his firm grip nor the fantastic light with which he [Rembrandt] would have painted such a subject. In the last century, Van Dijk praised the work as Flinck's masterpiece, especially because the artist had given Solomon a golden robe and none of the three colors that, on God's order were consecrated: purple, scarlet, and heavenly blue. He understood well that these three colors were not fit to adorn persons other than the high priest. ${ }^{66}$ We admire the painter's good understanding, but we also understand something else: when the artist limits himself by such eloquent pettiness, Dutch art rushes towards speedy decadence.

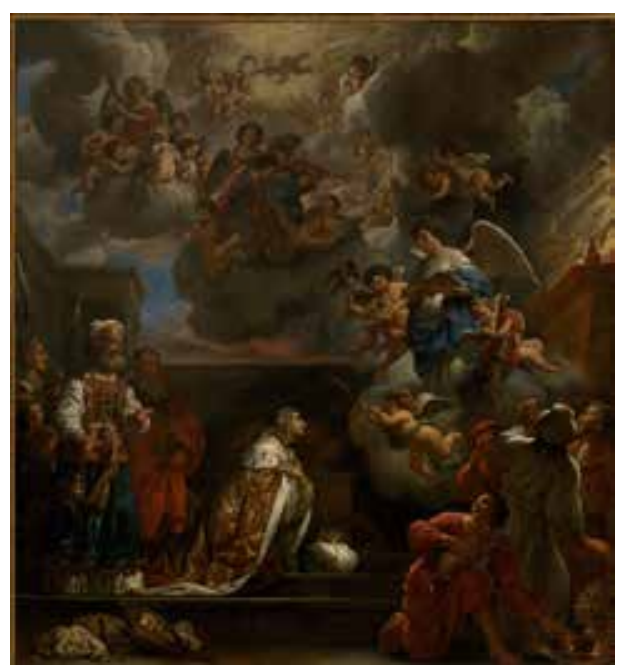

Fig. 13 Govert Flinck, Solomon's Prayer for Wisdom, 1658, Royal Palace, Amsterdam (artwork in the public domain; photo: Tom Haartsen)

Flinck's patrons, however, were very satisfied and paid him 1,000 guilders as a reward. We do not begrudge him the wage, but where we see him carry the heavy purse with gold to his well-furnished house on the Lauriergracht, we cannot suppress a sense of melancholy if we think how such a sum might have benefited the bankrupt genius who in that very year had to sell his house and art treasures at a public auction resulting from his financial troubles for which, as a nation, we feel still ashamed. ${ }^{67}$

Flinck painted yet another large canvas for the town hall: one of the chimneypieces in the burgomaster's room. It was probably painted before the Solomon, because the friezes in the burgomaster room had already been made in 1655 by Quellinus. In this painting, for which he received f1500, ${ }^{68}$ Flinck depicted how Marcus Curius declined the offered gold and his contentment with a meal of turnips [fig. 14]. In this painting, too, we admire the rich and judicious composition, a meticulously good line and a correct division of colors, in addition to a well thought-out expression of the contrast between the proud simplicity of the solemn Roman and the luxuriant appearance of the envoy, who wants to enable him to enjoy all the goods of the earth. There is much in the painting reminiscent of Rubens, but it lacks the glow and strength that inspired the great Antwerper. 


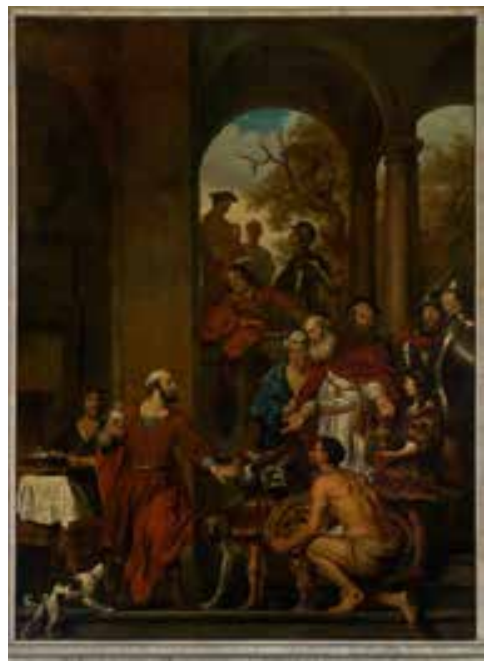

Fig. 14 Govert Flinck, Marcus Curius Dentatus, 1656,

Royal Palace, Amsterdam (artwork in the public

domain; photo: Tom Haartsen)

Similar work by Flinck would have been visible in the town hall had death not surprised him. In November 1659, he received a commission for twelve scenes, for f1000 apiece, to fill the lunettes in the vaults of the high galleries, or corridors, which, adjacent to the large central hall, run around both courtyards of the building and that nowadays are fragmented and separated from the central hall by wooden walls. Each year he was to deliver two of them. But before even one was finished, a short but fierce illness brought the painter to the grave (February 2, 1660) at the age of only forty-five years. This was without doubt too early for his family, but not too early for his fame -- although it is exaggerated to characterize him as "in the end deteriorating into an Italian fake [style]." ${ }^{69} \mathrm{~A}$ beautiful burial-coin was made in his honor [fig. 15], one that has served as an example of such coins into our own century. It is depicted in Havard ${ }^{70}$ and in Van Lennep's Von$d e l,{ }^{71}$ and it is present in the royal numismatic cabinet in The Hague. ${ }^{72}$ Although the inscriptions are engraved, the careful workmanship and its unusual type indicate that we are not dealing here (as usual) with a coin that a goldsmith had in stock and could engrave as required. This is a piece that was made especially for the occasion.

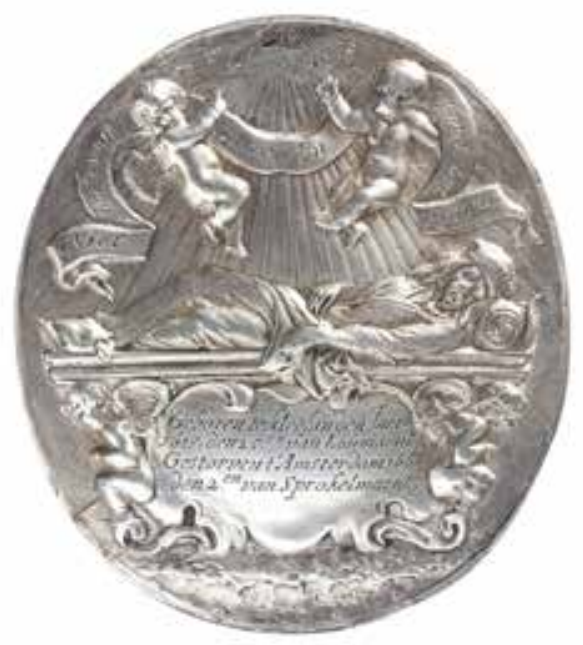

Fig. 15 Wouter Muller, Burial Coin of Govert Flinck, 1660, Teylers Museum, Haarlem, inv. no. TMNK 00660 (artwork in the public domain)

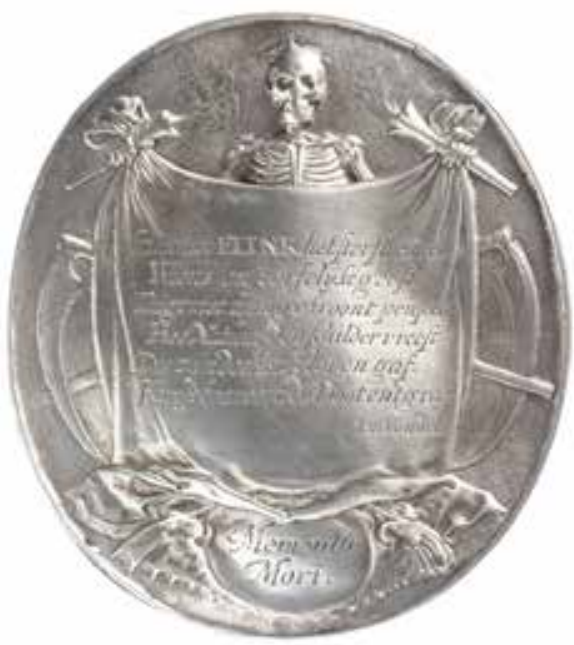

Fig. 15 Wouter Muller, Burial Coin of Govert Flinck, 1660, Teylers Museum, Haarlem, inv. no. TMNK 00660 (artwork in the public domain) 
Like Rembrandt and Van der Helst, Flinck left one son. ${ }^{73}$ This was Nicolaas Anthonie Flinck, whose birth I mentioned above. And just like Titus van Rijn and Lodewijk van der Helst, Nicolaas Flinck was skilled in the arts. This is apparent from an etching, in the Rijksprentenkabinet, which owns one of the rare impressions: a portrait of a young man with long hair, signed " $\mathrm{N}$. Flinck fecit (de N and F ligated)" [fig. 16]. It is considered to be his own portrait and the family resemblance makes this very likely. Little evidence indicates that the young Flinck had dedicated himself to the arts other than as a collector. ${ }^{74}$

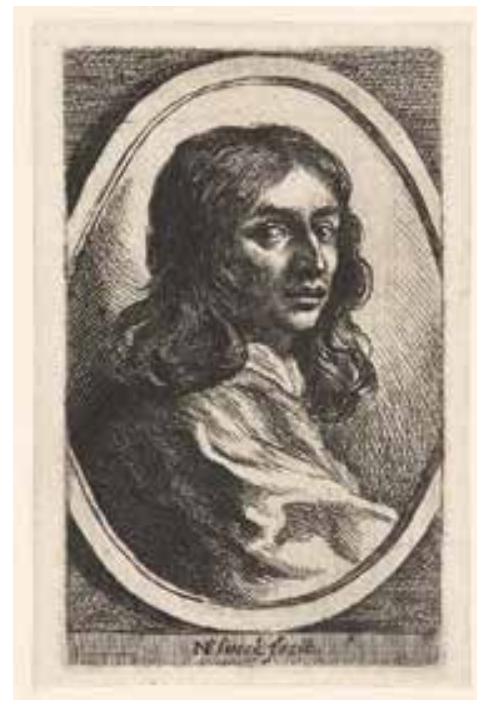

Fig. 16 Nicolaes Anthony Flinck, Self-Portrait, ca. 1665-80, Rijksmuseum Amsterdam, inv. no. RP-P1887-A-11809 (artwork in the public domain)

41 After his father's death he seems to have moved with his stepmother to the south of Holland, to join her family and that of his own mother. In the beginning of the next century, we find him back in Rotterdam en grand seigneur, in a beautiful house (presently the Hotel des Pays-Bas, in the Korte Hoogstraat, near the Passage), ${ }^{75}$ serving as a governor of the East India Company and married to the burgomaster Van Berckel's daughter. He gave Arnold Houbraken (not always correct) information regarding the biographical facts of his famous father. He owned a fairly good cabinet of paintings, partly left by Govert, which after the death of his only daughter was auctioned in Rotterdam on November $4,1754 .^{76}$

Flinck's protector, Huydecoper, soon followed him to the grave (October 26, 1661). He had lived through some happy years: in 1658 he had been treasurer and in 1659 and again in 1660 burgomaster. His only son Jan, who was born in 1625 and studied in Leiden in 1645, became an ensign (later lieutenant) in the twenty-eighth company, where his father was captain. ${ }^{77} \mathrm{He}$ accompanied his father to Berlin in 1655, married Sophia Coymans, his niece, after his return, became an alderman in 1656, and burgomaster in 1666. Regarding his sisters, the two eldest, Maria and Leonora, both married members of the Hinlopen family in 1642 and in 1657. The four others were still unmarried at their father's death and the house-poet Jan Vos, as an affably received guest, could sing of the beauty of Geertui, ${ }^{78}$ the homely care of Constantia, ${ }^{79}$ the erudition of Elisabeth, ${ }^{80}$ and the youth of Jacoba Sophia, ${ }^{81}$ until he too paid the toll of nature in July 1667. 
Tom van der Molen works as a project curator at the Amsterdam Museum. Among other things he worked there on a semi-permanent exhibition, Portrait Gallery of the Golden Age, that recently opened in the Hermitage Amsterdam and includes about a dozen of the Amsterdam civic guard paintings. He is a PhD student working toward a dissertation on Govert Flinck at Radboud University, Nijmegen, under Volker Manuth.

\section{Acknowledgements}

In the first paragraphs of "The Amsterdam Civic Guard Pieces within and Outside the New Rijksmuseum," D.C. Meijer expresses his strong desire that one day in the future all these civic guard pieces will be on display in a public place. Of course he is happy that the (then) new Rijksmuseum shows a good number of them, a nice improvement over the three on show previously in the Trippenhuis. Until a couple of months ago, we today could hardly claim an improvement in the visibility of the civic guard portraits. In 2013, the Rijksmuseum re-opened in its full capacity, but the number of civic guard portraits remained limited to artistic highlights by such artists as Rembrandt, Van der Helst, Hals, Flinck, Sandrart and Ketel. Moreover the focus was almost exclusively on the paintings' artistic merits and largely ignored the historical context in which these works of art functioned.

I am grateful that I was in a position to translate and annotate Meijer's texts because they provide, for the first time, an overview of these works in the context of the lives and times of those depicted. The annotations benefited greatly from two other projects I worked on and the contacts with colleagues and scholars who collaborated on these projects. The first is the Jaarboek Amstelodamum 2013 (http://www.lubberhuizen.nl/jaarboek-genootschap-amstelodamum-2013), an issue entirely devoted to the Amsterdam civic guard portraits. Under the title "De Amsterdamse schuttersstukken 1529 - 1656," essays (all in Dutch) deal with the function and use of the civic guard halls. Reconstructions of the portraits' original situation are published there, based on the list by G. Schaep and other sources (see JHNA 5:1 for a translation of Schaep's list). The sources are published in full in the Jaarboek.

The second is an ambitious presentation that the Amsterdam Museum, in collaboration with the Rijksmuseum, opened in the Hermitage Amsterdam in 2014: Portrait Gallery of the Golden Age (http://portraitgalleryofthegoldenage.com/). Some 15 civic guard portraits have been put on display there, together with that other genre of group portraiture, portraits of governors of charitable institutions. This does not entail a display of all 59 surviving Amsterdam Civic Guard Portraits - even if one counts the approximately 20 on display in the Rijksmuseum and the Amsterdam Museum. Nevertheless, this is a good step toward approaching the ideals of such $19^{\text {th }}$-century predecessors as Meijer. I thank all co-workers, colleagues and fellow authors for inspiration and new insights. I thank JHNA and its editors for their willingness to offer a place for the translation of D.C. Meijer's article and for their kind patience with my struggle to translate $19^{\text {th }}$-century Dutch into $21^{\text {st }}$-century English.

\section{List of Illustrations}

Fig. 1 Govert Flinck, Governors of the Arquebusiers Civic Guard Hall, 1642, Rijksmuseum Amsterdam, inv. no. SK-C-370 (on loan from the city of Amsterdam) (artwork in the public domain) 
Fig. 2 Govert Flinck, Isaac Blesses Jacob, ca. 1638, Rijksmuseum Amsterdam, inv. no. SK-A-110 (artwork in the public domain)

Fig. 3 Attributed to Arent Cornelisz Coster, Drinking Horn of the Arquebusiers Civic Guards, 1547, Rijksmuseum Amsterdam, inv. no. BK-AM-12 (on loan from the city of Amsterdam) (artwork in the public domain)

Fig. 4 Govert Flinck, Company of Albert Bas and Lucas Conijn, 1645, Rijksmuseum Amsterdam, inv. no. SK-C-371 (on loan from the city of Amsterdam) (artwork in the public domain)

Fig. 5 Govert Flinck, Company of Captain Joan Huydecoper and Lieutenant Frans van Waveren Celebrating the Treaty of Münster, 1650, Amsterdam Museum, inv. no. SA 7318 (artwork in the public domain). Below the painting is the nameplate (Amsterdam Museum, inv. no. KA 28881)

Fig. 6 Abraham Bloteling after Gerard Pietersz van Zijl, Portrait of Govert Flinck, ca. 1660-90, Rijksmuseum Amsterdam, inv. no. RP-P-BI-1819 (artwork in the public domain)

Fig. 7 Romeyn de Hooghe,Mardi Gras de Cocq a l'Ane (A Cock-and-Bull Carnival), 1690, British Museum, London, reg. no. 1868,0808.3396 (artwork in the public domain)

Fig. 8 Jacob Houbraken after Hendrik Pothoven after Govert Flinck, Portrait of Jean Appelman, ca. 1749-59, Rijksmuseum Amsterdam, inv. no. RP-P-OB-48.814 (artwork in the public domain)

Fig. 9 Hendrik Winter, Joan Huydecoper Is Offered a Cup, 1641, Rijksmuseum Amsterdam, inv. no. RP-P-OB-81.505 (artwork in the public domain)

Fig. 10 Abraham Bloteling after Jacob Ruisdael, The House of Joan Huydecoper, Seen from the Rear, with Workers Digging the Herengracht in the Foreground, ca. 1655-90, Rijksmuseum Amsterdam, inv. no. RP-P-BI-1861 (artwork in the public domain)

Fig. 11 Reinier Nooms, The Ferry to Leiden, ca. 1657-70, Rijksmuseum Amsterdam, inv. no. RPP-OB-20.506 (artwork in the public domain)

Fig. 12 Artus (I) Quellinus, Portrait Bust of Joan Huydecoper, 1654, Amsterdam Museum, inv. no. BB 208 (on loan from a private collection) (artwork in the public domain)

Fig. 13 Govert Flinck, Solomon's Prayer for Wisdom, 1658, Royal Palace, Amsterdam (artwork in the public domain; photo: Tom Haartsen)

Fig. 14 Govert Flinck, Marcus Curius Dentatus, 1656, Royal Palace, Amsterdam (artwork in the public domain; photo: Tom Haartsen)

Fig. 15 Wouter Muller, Burial Coin of Govert Flinck, 1660, Teylers Museum, Haarlem, inv. no. TMNK 00660 (artwork in the public domain) 
Fig. 16 Nicolaes Anthony Flinck, Self-Portrait, ca. 1665-80, Rijksmuseum Amsterdam, inv. no. RP-P-1887-A-11809 (artwork in the public domain)

${ }^{1}$ For the latest insights into the decoration of that hall, see Herman Colenbrander, "De decoratie van de Grote Zaal van de Kloveniersdoelen: Een vooropgezet plan?" and "Hoe hoog hing deNachtwacht? Een kwestie van ellen, voeten en duimen,"De Amsterdamse schuttersstukken 1529-1656 (Jaarboek Amstelodamum150 2013]): 218-37 and 238-75; and S. A. C. Dudok van Heel, "The Night Watch and the Entry of Marie de' Medici: A New Interpretation of the Original Place and Significance of the Painting," Rijksmuseum Bulletin 57 (2009): 5-41.

${ }^{2}$ Meijer is paraphrasing Houbraken's life of Flinck: A. Houbraken, De groote schouburgh der Nederlantsche konstschilders en schilderessen (Amsterdam, 1718-21), 2:18-27

${ }^{3}$ Meijer is paraphrasing Houbraken's life of Flinck (see note 2 above).

${ }^{4}$ [Meijer's note: In 1643 a Jacob Lambertsz Tempel is also mentioned in Leiden.]

${ }^{5}$ [Meijer's note: Flinck moved in with a former fellow townsman of his teacher, who was also related to Rembrandt, the painter and art dealer Hendrik Uylenburgh, where Rembrandt also lived or had his workshop at that time (Oud Holland, V 213).] A. Bredius and N. de Roever, "Rembrandt: Nieuwe bijdragen tot zijne levensgeschiedenis,"Oud Holland5 (1887): 210--27.

${ }^{6}$ It is no longer believed that Backer worked in Rembrandt's workshop. See Peter van den Brink, et al.Jacob Backer (1608/9-1651)(Zwolle: Waanders, 2008).

${ }^{7}$ Meijer probably refers toIsaac Blesses Jacob in the Rijksmuseum from 1638 (inv. no. SK-A-110) and the painting of the same subject in Museum Het Catharijneconvent (inv. no. MCC RMCC s131) from a few years earlier (ca. 1635). I am not sure which other blessings by Flinck he might have had in mind, or which ones of the same subject by other pupils. In the catalogue by J. W. von Moltke these paintings are no. 8 and no. 9, respectively: J. W. von Moltke,Govaert Flinck: 1615-1660(Amsterdam: Hertzberger, 1965).

${ }^{8}$ This is not entirely true. Flinck must have worked with Rembrandt in the Uylenburgh workshop for about a year around 1634-35. After that it was Rembrandt who left for independence (from Uylenburgh) and Flinck stayed, if we are to believe Sandrart, for "many years" to come. In 1637 Flinck is still mentioned as "living with Uylenburgh" as a buyer of prints in the sale of the collection of Jan Basse. In 1644 he buys his own house on the Lauriergracht. It may safely be assumed that he was independent by then. See F. Lammertse and J. van der Veen,Uylenburgh \& Son: Art and Commerce from Rembrandt to De Lairesse, 1625-1675(Zwolle: (Waanders, 2006); also Joachim von Sandrart,Teutsche Academie der Bau-, Bild- und Mahlerey-Künste, vol. 1 (Nuremberg, 1675), part 2, book 3, p. 319 (online version: http://ta.sandrart.net): "Er hielte sich lange Jahre auf bey dem berühmten Kunsthändler Ulenburg/ dem er viel ausbündige herrliche Contrafäte von eigner Hand hinterlaßen"; and SAA, 5073,Archief van de Weeskamer, no. 962, Sale of inventories Daniell Janss van Beuningen(sheets unnumbered, the mention is within the sale of the inventory of Jan Basse, on March 13, 1637. Among the other artists bidding for prints that day were Rembrandt, Nicolaes Eliasz Pickenoy, and Adriaan van Nieulandt).

${ }^{9}$ Herzog Anton Ulrich-Museum, Braunschweig, inv. no./cat. no. 252 (Von Moltke,Govaert Flinck, no. 140)

${ }^{10}$ The sitter is actually Flinck's nephew and later neighbor Dirck Jacobsz Leeuw (Von Moltke,Gov- 
aert Flinck, no. 211; presently in the Rembrandthuis on loan from the Mennonite church).

${ }^{11}$ State Hermitage Museum, St. Petersburg, inv. no. 783 (Von Moltke,Govaert Flinck, no. 263).

${ }^{12}$ Gemäldegalerie, Dresden, inv. no. 1600 (Von Moltke, Govaert Flinck, no. 181).

${ }^{13}$ Musée du Louvre, Paris, inv.no. 2373 (Von Moltke,Govaert Flinck, no. 139.

${ }^{14}$ Destroyed in 1945 (Von Moltke,Govaert Flinck, no. 367).

${ }^{15}$ The old man is the civic guard hall's innkeeper Jacob Pietersz. Nachtglas.

${ }^{16}$ [Meijer's note: Dr. Scheltema mistook it for Rendorp's coat of arms (Aemstel's Oudheid II, 136 and still even in theHistorische beschrijving der Schilderijen, 1879, p. 12, no. 31.] Pieter Scheltema, "Govert Flinck," Aemstel's Oudheid2 (1856): 127-43; Scheltema,Historische beschrijving der schilderijen van het stadhuis te Amsterdam (Amsterdam: Stadsdrukkerij, 1879).

${ }^{17}$ In the Amsterdam Prinsenhof, nowadays Hotel the Grand.

${ }^{18}$ Joachim von Sandrart,Company of Captain Cornelis Bicker and Lieutenant Frederick van Banchem, 1640, Rijksmuseum Amsterdam, inv.no. SK-C-393 (on loan from the city of Amsterdam).

${ }^{19}$ For the Van Dyckian inspiration of Flinck, see Hilbert Lootsma, “Tracing a Pose: Govert Flinck and the Emergence of the Van Dyckian Mode of Portraiture in Amsterdam,"Simiolus33 (2009): 221-36.

${ }^{20}$ Thomas de Keyser,De Amsterdamse burgemeesters vernemen de aankomst van Maria de Medici, 1638, Amsterdam Museum, inv. no. SB 5755 (on loan from the Mauritshuis, The Hague).

${ }^{21}$ [Meijer's note: Now printed in the meritorious work by J. A. Jochems,Amsterdams Oude Burgervendels. Amsterdam, 1888.]

${ }^{22}$ Depicted are: Jean Appelman, Rogier Ramsden, Pieter Waterpas, Joris de Wijze, Joan Huydecoper, Govert Flinck, Aart Jansz van Lier, Nicolaes Oetgens van Waveren, Pieter Meffert, Frans Oetgens van Waveren, Nicolaas van Haag, Johannes van den Haag, Jan Stuurman, Jacob van Campen, Johannes Doavenne, and Albert ten Brink.

${ }^{23}$ [Meijer's note: Together they were later brought from the Crossbow Archers Civic Guard Hall to the big war council room in the town hall and from there to the Trippenhuis.] Bartholomeus van der Helst,Company of Captain Cornelis Witsen and Lieutenant Johan Oetgens van Waveren Celebrating the Treaty of Münster (The Civic Guards Meal), 1648, Rijksmuseum Amsterdam, inv. no. SK-C-2 (on loan from the city of Amsterdam). See JHNA 6, no. 1 (fig. 1): http://jhna.org/index. $\mathrm{php} / \mathrm{past}$-issues/volume-6-issue-1-2014/255-the-amsterdam-civic-guard-pieces.

${ }^{24}$ [Meijer's note: Of course the list of names that is presently below the painting is not the original one. There are some trivial differences with the list that Van Dijk (1758) published, no. 15 is called Van der Hoog there, not Van der Haag. Also, on a list that I found between the papers that A. D. de Vries left, unfortunately without a clue where he had derived it from. In this list no. 6 is called Zamsden, not Ramsden. Ramsden is correct, however.] Amsterdam Museum, inv. no. KA 28881. ${ }^{25}$ [Meijer's note: That he did not belong to the lower ranks of society appears not only from the spurs on his boots in Flinck's painting, but also the appearance of his name on the list of the "puyck der Burger Ruyteren" [the elite of the city cavalry], that introduced Henriette Marie of England to the city in 1642, evident in the print of that entry by Nolpe after Potter. According to a communication by Mr. Bredius he was a glove maker and German by birth.] Pieter Meffert (?-1662) was a maker of playing cards from Zoelen (near Tiel). He is mentioned in the Amsterdam archives from 1631 onwards. Some of his playing cards are still in the collection of the Bibliothèque nationale de France in Paris. Imagery on this website: http://www.speelkaartenmuseum.nl/antiek/ pages/mefferdt.htm. 
${ }^{26}$ Jean Appelman (1608-1694) was a whaling-ship owner, train oil merchant and an importer of French goods. He was also installed in the council in 1672 by Stadhouder Willem III and became burgomaster in 1688.

${ }^{27}$ [Meijer's note:Mardi Gras de Cocq a l'Ane of Franse Kael-ender, probably by Romein de Hooghe; Anoo 1690.]

${ }^{28}$ Jacob Houbraken,Jean Appelman.,Amsterdam Museum, inv. no. A 16793: http://hdl.handle. net/11259/collection.72252

${ }^{29}$ [Meijer's note: His father Louis Victors was a herald between Amsterdam and Dordrecht and lived in the Hoogstraat, later probably in "de zilveren spiegel" in the Kalverstraat, from which street our painter married in 1642, aged twenty-two, to Jannetje Bellers. He was still alive in 1670. See the biographical notes by A. D. de Vries Az. In this journal (IV, 220) from which it also appears that Victors had good, friendly relations with several ministers. This perhaps explains his preference for biblical scenes and the commission by the Diaconie orphanage (without doubt when the institution was built in 1657). He delivered two masterpieces there, described by De Vries inDe Gidsof 1876 and by me in Wandeling door de zalen van de Hist. Tent.Some mistakes in design that he shares with Claes Elias (See Dr. Six in this journal IV, 100) would allow us to consider him a pupil of this master, although he had also visited Rembrandt's workshop, whose influence is most clearly visible in hisPortrait of a Girlin the Louvre of 1640, where he still signed Fictoors. Victors can be characterized particularly, as in the Museum van der Hoop, by his lively village scenes, full of humor, that do not resort to the disgusting drunk scenes with which so many of his most talented contemporaries annoy us.] A. D. de Vries, "Biografische Aanteekeningen,"Oud Holland 4 (1886): 215-24; A. D. de Vries, "De schilderkunst op de historische tentoonstelling te Amsterdam," De Gids40 (1876): 552; D. C. Meijer Jr., Wandeling door de zalen der historische tentoonstelling van Amsterdam(Amsterdam,) 1876; J. Six, "Nicolaes Eliasz. Pickenoy,"Oud Holland4 (1886): 81-108.

${ }^{30}$ Jacob van Campen (1598-1668).

${ }^{31}$ [Meijer's note:Beschrijving der schilderijen op 't stadhuis, p. 49.] Jan van Dyk,Kunst en Historiekundige beschryving en aanmerkingen over alle de schilderyen op het Stadhuis te Amsterdam(Amsterdam: Yver, 1758).

${ }^{32}$ Huygens wrote a poem entitledVier en vlam. Aen ioff. T. Visschers, niewgetroude met s. ${ }^{r}$ Krombalck om voorspraeck bij ioff. Machteld van Kampen [Fire and flame. To Mrs. Tesselschade Visschers, newlywed wit Mr. Crombalch to [ask her to] mediate with Ms. Machteld van Campen]. Constantijn Huygens, Gedichten, Deel 2: 1623-1636,ed. J. A. Worp (Groningen: Wolters, 1893), 42-49. She was buried in the Oude Kerk on May 13, 1626. SAA, DTB, inv. no. 1044,Burial registers Oude Kerk, f. 128vo.

33 [Meijer's note: He did not wear the standard for long. In 1650 he was replaced as an ensign by the captain's son (Van Loon,Beschrijving der Nederlandse HistoriepenningenII, 348).] Gerard van Loon,Beschrijving der Nederlandsche Historiepenningen(The Hague, 1723-31), 2:348.

${ }^{34}$ Joan (1613-1670), Frans (1619-1651), and Nicolaes Oetgens van Waveren (1622-1684) were the sons of Anthony Oetgens van Waveren (1585-1658), who served as burgomaster seven times. His oldest son Joan was also elected burgomaster, but only once, in 1670. J. E. Elias, De Vroedschap van Amsterdam, 1578-1795(Amsterdam: Israel, 1963), 1:331, no. 107, and 509, no. 184 (digital version: http://resources.huygens.knaw.nl/retroboeken/elias/)

${ }^{35}$ Jan Vos,Alle de Gedichten(Amsterdam: Lescailje, 1662), 540-41: http://www.dbnl.org/tekst/ vos 002alle01 01/vos 002alle01 01 0241.php 
${ }^{36}$ Jan Jacobsz Bal Huydecoper (1541-1624) was a manufacturer and merchant in leather (Huydecoper literally meaning skin buyer).

${ }^{37}$ Vos, Alle de Gedichten, 215-16: "Blyde Inkomst van den Wel-Edelen Gestrengen Heer Joan Huydekooper, Ridder, Heer van Maarseveen, Neerdyk, \&c. Burgermeester, Raadt, en Gezant der Stadt Amsterdam aan Zyne Keurvorstelyke Doorluchtigheit van Brandenburgh.” http://www.dbnl. org/tekst/vos 002alle01 01/vos 002alle01 01 0166.php - 170

${ }^{38}$ Jan Jacobsz Bal Huydecoper married Elisabeth van Gemen (1566-1652) in 1596, when he was about fifty-five. She was his second wife, as he had been previously married to Lijsbeth Hendricksdr Wou, who gave him seven children. Joan Huydecoper was the only child from the second marriage. Elias, De Vroedschap, 92, no. 32. Joan Huydecoper was not born in 1601 as Meijer claims but in 1599.

${ }^{39}$ [Meijer's note: Her father's name was Balthasar; her (Maria Coymans') mother was a certain De Piquer, and therefore probably belonged to the family of the wife of Governor-General Laurens Reael.]

${ }^{40}$ [Meijer's note: Vos, Gedichten, Editie 1662, p. 210.] Vos,Alle de Gedichten, 210.

${ }^{41}$ [Meijer's note: Nowadays inhabited by the attorney Asser and numbered 548. According to the image in Vingboons the chimneys, that used to protrude from the roof, one could read the year of building 1639. As a consequence of the broadening of the upper floor, the gable nowadays is not in the original state. "Des Heeren Huydecoopers huis van achteren" (Mr. Huydecopers house from the back) was drawn by Ruisdael when he made a sketch of the digging of the bend in the Herengracht in 1664. That drawing, used for print, was published by A. Blooteling.]

${ }^{42}$ Unfortunately, the house was hit by a crashing English bomber in 1943.

${ }^{43}$ [Meijer's note: Vos, Gedichten, Editie 1662; p. 217, 281, 222, 257.] Flinck also had a role to play in that visit since he provided the lunettes of the town hall with watercolor sketches of the Batavian cycle. He was paid for them on December 3, 1659. SAA, 5039,Archief van de Thesaurieren Ordinaris, inv. no. 2: resoluties 01/04/1657-16/10/1664, f. 42v.

${ }^{44}$ [Meijer's note: De Vries en de Jonge,Nederlandse Gedenkpenningen verklaard, II 37.] A silver version is kept in the Amsterdam Museum, inv. no. PA 465.

${ }^{45}$ [Meijer's note: Vos, p. 215.] Vos,Alle de Gedichten, 215-16: "Blyde Inkomst van den Wel-Edelen Gestrengen Heer Joan Huydekooper, Ridder, Heer van Maarseveen, Neerdyk, \&c. Burgermeester, Raadt, en Gezant der Stadt Amsterdam aan Zyne Keurvorstelyke Doorluchtigheit van Brandenburgh.”: http://www.dbnl.org/tekst/vos 002alle01 01/vos 002alle01 01 0166.php

${ }^{46}$ Joost van de Vondel, "Inwydinge van 't Stadhuis te Amsterdam," inDe werken van Vondel, Deel 5: 1645-1656,ed. J. F. M. Sterck (Amsterdam, 1931), 856-904: http://www.dbnl.org/tekst/vond001dewe05 01/vond001dewe05 01 0208.php

The passage where Huydecoper is named as one of the members of the commission is on p. 866 . ${ }^{47}$ [Meijer's note: This portrait was engraved by Holsteyn. The original (dated 1646) is, as Mr. E. W. Moes told me, nowadays in the possession of Jhr. Mr. v.d. Wijck in The Hague.]

${ }^{48}$ [Meijer's note: Vos, p. 198.] Vos,Alle de Gedichten,198-99: http://www.dbnl.org/tekst/vos 002alle01 01/vos 002alle01 01 0146.php

${ }^{49}$ On loan to the Amsterdam Museum since 1954: http://hdl.handle.net/11259/collection.89080

${ }^{50}$ [Meijer's note:Korenbloemen, 1658, p. 768.] Constantijn Huygens,Gedichten, Deel 6: 16561661,ed. J. A. Worp (Groningen, 1896), 63: http://www.dbnl.org/tekst/huyg001jawo14 01/huyg001jawo14 01 0001.php

${ }^{51}$ Joost van de Vondel, "Inwyjinge der Schilderkunste, Op Sint Lukas Feest," inDe werken van 
Vondel, Deel 5: 1645-1656,ed. Sterck (Amsterdam, 1931), 820: http://www.dbnl.org/tekst/vond001dewe05 01/vond001dewe05 01 0191.php\#187

See also Thomas Asselijn,Broederschap der Schilderkunst(Amsterdam, 1654) for all the texts recited during that feast. The feast took place in the same room where the civic guard painting by Flinck discussed here originally hung. Tom van der Molen, "Apelles en Apollo in de Voetboogdoelen: Sint-Lucasfeesten tussen schuttersstukken," De Amsterdamse schuttersstukken: Inrichting en gebruik van de doelengebouwen in de zeventiende eeuw(Jaarboek Amstelodamum150 2013]): 192-217.

${ }^{52}$ Gover, ik verschrik voor Kampen, [Gover, I am scared off by quarreling] Vechten, drinken en slampampen, [fighting, drinking and debauching] Razen, buld'ren, trappen, trampen, [raging, roaring, kicking, tramping] Dat gespuis aan boort te klampen, [to clamp that rabble by the collar] Maag en darmen vol te stampen, [to cram full stomach and bowels] By de kaers, of by de lampen, [by candle or lamplight] Hier uit spruiten duizent rampen, [from this a thousand disasters stem] Hooft-pijn, zinkingen en dampen, [headache, collapsing and foul odors] Zenu-krimpingen en krampen. [twitches and convulsions] Wiltge blijven? ick ga schampen. [Do you want to stay? I am off] It is not very likely that the "Gover" who is addressed in this poem is indeed Flinck, nor is it clear on what occasion this poem was made. In fact, Meijer is paraphrasing romanticizing notes of earlier writers. Joost van den Vondel,De werken van Vondel,Deel 8: 1656-1660 (Amsterdam, 1935), 691: http://www.dbnl.org/tekst/vond001dewe08 01/vond001dewe08 01 0217.php

${ }^{53}$ [Meijer's note: According to Havard (L’Art et les Artistes HollandaisII, 81) Flinck was a Lutheran. Evidence for this has not become clear to me. I searched in vain for the name of Flinck's child in the Lutheran baptismal registers.] There is no real proof that Flinck was a Mennonite, but it is likely, since both his first teacher and his family (the de Leeuw family) in Amsterdam were. On August 24, 1651 Flinck was baptized as a Remonstrant: SAA, 612,Inventaris Archief van de Remonstrantse Gemeente, no. 284, Doopregister, f. 55.

${ }^{54}$ [Meijer's note: Of course his honorable life style did not exclude painting after nude models. The painter who depicted Margaretha van Wullen, the mistress of Nicolaas Heinsius, in the nude was none other than Flinck (see Ten Brink,Dr. Nic. Heinsius, p. 15). Mr. Bredius found a testimony before notary De Ghryp at the request of Heinsius, by Flinck's maidservants and one of his neighbors, that they had seen the said portrait, together with those of Margaretha's sisters Catrina and Anna "as naked as one could be painted, asleep on a pillow in a very dishonorable fashion." They added that Flinck's pupils had spied the damsels during their dishonorable frolicking with young men at the bleaching ground of a neigboring house. The ladies seem therefore to have lived on the Lauriergracht then. Maybe they were (although Heinsius had met Margaretha in Stockholm) daughters of an Amsterdam preacher: Jan van Wullen served the Lutheran church in Amsterdam from 1625 until 1640 and what little the church chronicles have to say about him is not good. The case is not worth further investigation in my opinion.] SAA, 5075, NAA, C. De Grijp, no. 2573, f. 301-302, 27 July 1657. A year later Flinck, together with Willem Strijcker, Ferdinand Bol, Nicolaas van helt Stockade, and Jacob van Loo testified that they had drawn after a nude model together. SAA, 5075, NAA, G. Borsselaer, no. 1474, 27 July 1658.

${ }^{55}$ At least shortly before 1651 he and his wife visited Cleves, as he himself states in the autopsy report (see below). Not only his parents remained in Cleves (they were still alive in 1649), his 
brother lived in Emmerich, only a short distance from his native town. SAA, DTB, inv. no. 680,Ondertrouwregisters pui, f. 127: 1 juli 1649

${ }^{56}$ [Meijer’s note: Vos, Gedichten, Edition 1662, p. 524.] Jan Vos, “ Op de Beeldekas van G. Flink,"Alle de Gedichten, 424-25.

57 [Meijer's note: He does not seem to have remained in Rotterdam, because he made his testament on October 4, 1652 (which follows later) before the Amsterdam notary J. van Loosdrecht.] When he made that testament Marten Thoveling was living on the Anjeliersgracht. SAA, 5075, NAA, Jacob van Loosdrecht, no. 1971, f. 458.

58 [Meijer's note: in hisHeel- en geneeskonstige aanmerkingen, Amst. 1668, p. 287.] Job van Meekeren,Heel- en geneeskonstige aenmerkingen(Amsterdam, 1668), f. 287-294.

${ }^{59}$ Henry Havard,Lart et les artistes hollandais, vol. 2 (Paris, 1880), 114-16.

${ }^{60}$ Meijer could have also cited from the testament to prove that this was a marriage out of love after all. The couple states that if one of them should die and they should have no children then the other would inherit all the other's possessions "om de echte liefde die sij malcanderen toedragen" [because of the real love they feel for each other]. SAA, 5075, NAA, Jacob van Loosdrecht, no. 1971 , f. 48.

${ }^{61}$ SAA, 5073,Archief van de Weeskamer, Ïnbrengregisters, no. 801: '30'. 1656 mei-1660 november 16, f. 5vo; Havard, Lart et les artistes hollandais,147-48.

${ }^{62}$ SAA, 5075, NAA, Jacob van Loosdrecht, no. 1971, f. 458.

${ }^{63}$ SAA, DTB, inv. no. 683,Ondertrouwregisters, f. 28: 6 mei 1656.

${ }^{64}$ Joost van den Vondel, "Ter bruilofte Van den kunstrijcken Govaert Flinck, En de E. Iongkvrouwe, Sofia van der Hoeven," De werken van Vondel, Deel 8: 1656-1660(Amsterdam, 1935), 199-201: http://www.dbnl.org/tekst/vond001dewe08 01/vond001dewe08 01 0012.php

${ }^{65}$ [Meijer's note: From Quellinus's bill it becomes clear that the friezes for the mantelpiece were made by him in 1656 and Flinck received payment for the painting on 1 April 1657. I belief I can therefore propose 1656 for theSolomon.] Flinck was paid on July 12, 1658: SAA, 5039,Archief van de Thesaurieren Ordinaris, inv. no. 2: resoluties 01/04/1657-16/10/1664, f. 12, 12 juli 1658. The painting itself is signed and dated 1658.

${ }^{66}$ Van Dyk,Kunst en Historiekundige,123-25.

${ }^{67}$ [Meijer's note: That Rembrandt would have snubbed working to decorate the town hall is devoid of all historical support and has been refuted adequately in this journal (Vol. II, p. 90). The presumption uttered in that article, that the enmity of Witsen would have prevented the acceptance of Rembrandt's work, shows too low an esteem for the burgomaster in my opinion. Rembrandt's demands were probably too high or he did not finish on time. The sketch of what Rembrandt would have wanted to make for the town hall can probably be found nowadays in the Museum Boijmans in Rotterdam.]

${ }^{68}$ [Meijer's note: Scheltema,Aemstel's Oudheid VI, 38.] The painting is signed and dated 1656.

${ }^{69}$ [Meijer's note: Van Vloten,Nederlands Schilderkunst, p. 290.]

${ }^{70}$ Havard,Lart et les artistes hollandais, 78-79.

${ }^{71}$ Jacob van Lennep,De werken van Vondel(Amsterdam, 1855-69).

${ }^{72}$ This collection became part of the Geldmuseum, which was forced to close in 2013. The collection is now part of the National Numismatic Collection under the care of the Dutch National Bank: http://www.dnb.nl/over-dnb/nationale-numismatische-collectie/index.jsp

${ }^{73}$ Meijer makes a mistake here, Rembrandt left only a daughter, Cornelia. His son Titus died in 1668 , a year before his father. 
${ }^{74}$ An van Camp, “Etchings by Drawings Collector Nicolaes Flinck (1646-1723),"Print Quarterly27 (2010): 371-81.

${ }^{75}$ Destroyed in May 1940.

${ }^{76} \mathrm{G}$. Hoet and P. Terwesten,Catalogus of naamlyst van schilderyen, Part 3 (The Hague, 1770), $100-104$.

77 [Meijer's note: Jochems,Amsterdams oude burgervendels (Amsterdam 1888), p. 59. Van Loon,Beschrijving der Nederlandsche Historiepenningen II 348.] Jochems, Amsterdams Oude Burgervendels, 59; Van Loon,Beschrijving der Nederlandsche Historiepenningen, 2:348.

78 [Meijer's note: Vos, Gedichten, edition 1662, p. 193, 255, 385. She married David d'Alblain on 5 December 1662 (Vos second vol. [ed. 1671] 204).] Vos, Alle de Gedichten, 193, 255, 385.

${ }^{79}$ [Meijer's note: Vos,Gedichten, edition 1662, p. 201, 458.] Vo s,Alle de Gedichten, 201, 458.

${ }^{80}$ [Meijer's note: Vos, Gedichten, edition 1662, p. 194, 459.] Vos, Alle de Gedichten, 194, 459.

${ }^{81}$ [Meijer's note: Vos,Gedichten, edition 1662, p. 201, 275. She married Willem Bartolotti van den Heuvel on 17 October 1665 (Vos second vol. [ed. 1671] 227).] Vos,Alle de Gedichten, 201, 275, 277.

\section{Bibliography}

\section{Unpublished Primary Sources}

SAA, DTB, inv. no. 680, Ondertrouwregisters pui, f. 127: 1 juli 1649

Marital vows of Ameldonck Flinck, Govert's brother, 1649

SAA, DTB, inv. no. 683, Ondertrouwregisters, f. 28: 6 mei 1656

Marital vows Flinck and Sophia van der Houve, 1656

SAA, DTB, inv. no. 1044, Burial registers Oude Kerk, f. 128vo

Burial of Machteld van Campen, 1624

SAA, 612, Inventaris Archief van de Remonstrantse Gemeente, no. 284, Doopregister, f. 55

Flinck's baptism as a Remonstrant, 1651

SAA, 5039, Archief van de Thesaurieren Ordinaris, inv. no. 2: resoluties 01/04/1657-16/10/1664, f. 12, 12 juli 1658

Payment for Solomon's Prayer for Wisdom, 1658

SAA, 5039, Archief van de Thesaurieren Ordinaris, inv. no. 2: resoluties 01/04/1657-16/10/1664, f. $42 \mathrm{v}$

Payment to Flinck for the watercolor sketches in the lunettes of the town hall, 1659

SAA, 5073, Archief van de Weeskamer, Ïnbrengregisters, no. 801, '30'. 1656 mei-1660 november 16 , f. 5 vo

Flinck registering Nicolaes Flinck's share of his mother's inheritance at the orphan chamber, 1656 SAA, 5073, Archief van de Weeskamer, no. 962, Sale of inventories Daniell Janss van Beuningen Mention of Flinck as living with Uylenburgh, 1637

SAA, 5075, NAA, G. Borsselaer, no. 1474, 27 July 1658

Flinck, together with Willem Strijcker, Ferdinand Bol, Nicolaas van Helt Stockade, and Jacob van Loo testify that they have drawn after a nude model together, 1658

SAA, 5075, NAA, C. De Grijp, no. 2573, f. 301-302, 27 July 1657

Testimony that Flinck made a nude painting of Margaretha van Wullen, 1657

SAA, 5075, NAA, Jacob van Loosdrecht, no. 1971, f. 48 
Testament of Flinck and Ingitta Thoveling, 1646

SAA, 5075, NAA, Jacob van Loosdrecht, no. 1971, f. 458

Testament of Marten Thoveling, 1652

\section{Published Primary and Secondary Sources}

Asselijn, Thomas. Broederschap der Schilderkunst. Amsterdam, 1654.

Bredius, A., and N. de Roever. "Rembrandt: Nieuwe bijdragen tot zijne levensgeschiedenis." Oud Holland 5 (1887): 210-27.

Brink, Peter van den, et al. Jacob Backer (1608/9-1651). Zwolle: Waanders, 2008.

Camp, An van. "Etchings by Drawings Collector Nicolaes Flinck (1646-1723)." Print Quarterly 27 (2010): 371-81.

Colenbrander, Herman. "De decoratie van de Grote Zaal van de Kloveniersdoelen: Een vooropgezet plan?" De Amsterdamse schuttersstukken 1529-1656 (Jaarboek Amstelodamum 150 2013]): 218-37.

Colenbrander, Herman. "Hoe hoog hing de Nachtwacht? Een kwestie van ellen, voeten en duimen." De Amsterdamse schuttersstukken 1529-1656 (Jaarboek Amstelodamum 150 2013]): 238-75. Dudok van Heel, S. A. C. "The Night Watch and the Entry of Marie de' Medici: A New Interpretation of the Original Place and Significance of the Painting." Rijksmuseum Bulletin 57 (2009): 5-41. Dyk, Jan van. Kunst en historiekundige beschryving en aanmerkingen over alle de schilderyen op het Stadhuis te Amsterdam. Amsterdam: Yver, 1758

Elias, J. E. De Vroedschap van Amsterdam, 1578-1795. 2 vols. Amsterdam: Israel, 1963.

Havard, Henry. Lart et les artistes hollandais. Vol. 2. Paris, 1880.

Hoet, G., and P. Terwesten. Catalogus of naamlyst van schilderyen. Part 3. The Hague, 1770.

Houbraken, A. De groote schouburgh der Nederlantsche konstschilders en schilderessen. 3 vols.

Amsterdam, 1718-21.

Huygens, Constantijn. Gedichten. Edited by J. A. Worp. 10 vols. Groningen: Wolters, 1892-1899

Jochems, J. A. Amsterdams Oude Burgervendels. Amsterdam, 1888.

Lammertse, F., and J. van der Veen. Uylenburgh \& Son: Art and Commerce from Rembrandt to De Lairesse, 1625-1675. Zwolle: Waanders, 2006.

Lennep, Jacob van. De werken van Vondel. Amsterdam, 1855-69.

Loon, Gerard van. Beschrijving der Nederlandsche Historiepenningen. 4 vols. The Hague, 1723-31.

Lootsma, Hilbert. "Tracing a Pose: Govert Flinck and the Emergence of the Van Dyckian Mode of Portraiture in Amsterdam." Simiolus 33 (2009): 221-36.

Meekeren, Job van. Heel- en geneeskonstige aenmerkingen. Amsterdam, 1668.

Meijer, D. C., Jr., Wandeling door de zalen der historische tentoonstelling van Amsterdam. Amsterdam, 1876.

Molen, Tom van der. "Apelles en Apollo in de Voetboogdoelen: Sint-Lucasfeesten tussen schuttersstukken." De Amsterdamse schuttersstukken: Inrichting en gebruik van de doelengebouwen in de zeventiende eeuw (Jaarboek Amstelodamum 150 2013]):192-217.

Moltke, J. W. von. Govaert Flinck: 1615-1660. Amsterdam: Hertzberger, 1965.

Sandrart, Joachim von. Teutsche Academie der Bau-, Bild- und Mahlerey-Künste. Vol. 1. Nuremberg, 1675.

Scheltema, Pieter. “Govert Flinck.” Aemstel's Oudheid 2 (1856): 127-43.

Scheltema, Pieter. Historische beschrijving der schilderijen van het stadhuis te Amsterdam. Amsterdam: Stadsdrukkerij, 1879. 
Six, J. “Nicolaes Eliasz. Pickenoy." Oud Holland 4 (1886): 81-108.

Vondel, Joost van de. De werken van Vondel. Edited by J. F. M. Sterck. 10 vols. Amsterdam, 1927-37.

Vos, Jan. Alle de Gedichten. Vol. 1. Amsterdam: Lescailje, 1662.

Vries, A. D. de. "De schilderkunst op de historische tentoonstelling te Amsterdam." De Gids 40 (1876): 552.

Vries, A. D. de. "Biografische Aanteekeningen." Oud Holland 4 (1886): 215-24.

Vries, J. de, and J. C. de Jonge. Nederlandse Gedenkpenningen verklaard. Amsterdam, 1829/37.

Recommended citation:

D.C. Meijer Jr. (Tom van der Molen, translator), "The Amsterdam Civic Guard Pieces within and outside the New Rijksmuseum Pt. 5: Govert Flinck," JHNA 7:2 (Summer 2015) 